\title{
Experimental Simulation of the Interaction of Slag and Hot Metal with Coke at the Bosh Region of Blast Furnace
}

\author{
Anrin Bhattacharyya', Johannes Schenk', Michael Jäger', Hugo Stocker², and Christoph Thaler ${ }^{3}$ \\ ${ }^{1}$ Montanuniversität Leoben, Leoben, Austria \\ ${ }^{2}$ voestalpine Stahl Donawitz $\mathrm{GmbH}$, Leoben, Austria \\ ${ }^{3}$ voestalpine Stahl GmbH, Linz, Austria
}

Received November 2, 2016; accepted November 15, 2016; published online December 12, 2016

\begin{abstract}
Coke is the only raw material which remains solid even in the lowest zone of a blast furnace. The bed-permeability in the bosh zone of the blast furnace is maintained by the solid coke structure. The wetting behaviour of slags in the coke bed of the bosh region in a blast furnace plays a very important role in the process by directly influencing the free movement of the burden and furnace gas and thereby affecting the fuel consumption. Cokes of unsuitable quality will lead to lower permeability in the bosh zone and hinder the furnace operation. In this work, various industrial coke samples are treated with slags of different basicities in a drop-shape analysis facility at a high temperature similar to process conditions. The coke samples have been treated under standard CRI (Coke Reactivity Index) test conditions beforehand in order to simulate the process more closely. The results display the variations in wetting behaviour, temperature, and time for different coke and slag combinations as a function of coke properties and slag compositions. The wetting behaviour at the coke/hot metal interface has also been investigated. The results provide a better understanding of the solid-liquid interaction which takes place in the bosh region of the blast furnace.
\end{abstract}

Keywords: Coke, Bosh slag, Wetting, Hot metal, Blast furnace, CRI test

Experimentelle Simulation der Wechselwirkung von Schlacken und Roheisen mit Koks in der Rastregion des Hochofens

Zusammenfassung: Koks ist der einzige Rohstoff, der auch in der niedrigsten Zone des Hochofens fest bleibt. Die Bettpermeabilität in der Blasenzone des Hochofens wird durch die feste Koksstruktur aufrechterhalten. Das Benetzungs-

M. Eng. A. Bhattacharyya $(\triangle)$

Montanuniversität Leoben,

Leoben, Austria

anrin.bhattacharyya@unileoben.ac.at verhalten von Schlacken in der Rastregion eines Hochofens spielt eine sehr wichtige Rolle für die Prozesseffizienz durch direkte Beeinflussung der freien Bewegung von Möller und Ofengas und damit für den Brennstoffverbrauch. Kokse von ungeeigneter Qualität führen zu einer niedrigeren Permeabilität in der Rastzone und behindern den Ofenbetrieb. In dieser Arbeit werden verschiedene industrielle Koksproben mit Schlacken verschiedener Basizität in einer Tropfenformanalysenvorrichtung bei hoher Temperatur untersucht, die den Verfahrensbedingungen in der Rast des Hochofens ähnlich ist. Um möglichst prozessnahe Bedingungen zu erreichen, wurden die Koksproben zuvor mit Standard-CRI (Coke Reactivity Index) Testbedingungen behandelt Die Ergebnisse zeigen die Variationen von Benetzungsverhältnis, Temperatur und Zeit für verschiedene Koks- und Schlackenkombinationen als Funktion von Kokseigenschaften und Schlackenzusammensetzungen. Das Benetzungsverhalten an der Koks/Roheisen-Grenzfläche wurde ebenfalls untersucht. Die Ergebnisse liefern ein besseres Verständnis der Feststoff-Flüssig-Wechselwirkung, die in der Rastzone des Hochofens stattfindet.

Schlüsselwörter: Koks, Schlacke, Benetzung, Roheisen, Hochofen, CRI Versuch

\section{Introduction}

The permeability of the bosh zone of a blast furnace greatly affects its performance. Coke plays the most crucial role in maintaining bed permeability and thereby ensuring a proper gas flow through the bed. After passing through the stack, the burden materials reach the bosh zone where softening and melting are started. The major exception is coke as it still remains in the solid state. Coke is the only raw material which remains solid at the lowest zone of the blast furnace. Before reaching the bosh region, coke suffers both chemical and mechanical degradation 


\begin{tabular}{|lllllllll|}
\hline $\begin{array}{l}\text { TABLE 1: } \\
\text { Slag properties }\end{array}$ & $\mathbf{C a O}(\%)$ & $\mathbf{M g O}(\%)$ & $\mathbf{A l}_{2} \mathbf{O}_{3}$ (\%) & $\mathbf{S i O}_{2}$ (\%) & $\mathbf{B 2}$ & $\mathbf{B 4}$ & $\begin{array}{l}\text { Viscosity } \\
\text { (Poise) }\end{array}$ & Remarks \\
\hline Slag I & 39.5 & 11.8 & 10 & 38.7 & 1.02 & 1.05 & 1.362 & Low Basicity \\
\hline Slag II & 43.2 & 10.4 & 8.3 & 38.1 & 1.13 & 1.15 & 1.214 & $\begin{array}{l}\text { Medium } \\
\text { Basicity }\end{array}$ \\
\hline Slag III & 52.6 & 4.5 & 4.7 & 38.2 & 1.38 & 1.08 & 1.036 & $\begin{array}{l}\text { High Basic- } \\
\text { ity }\end{array}$ \\
\hline Slag IV & 35 & 10.7 & 27 & 27.3 & 1.28 & 0.84 & 1.544 & $\begin{array}{l}\text { High Alu- } \\
\text { mina }\end{array}$ \\
\hline
\end{tabular}

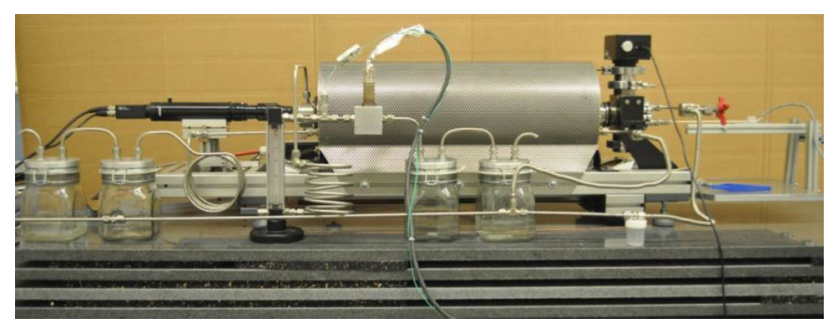

Fig. 1: Furnace for DSA tests

during its descent through the stack by Boudouard reaction and simultaneous mechanical abrasion respectively. The coke becomes more porous than its original structure after being treated by reactive gases [1]. Nevertheless, the bed permeability in this zone is maintained by the solid coke structure. The coke must possess a certain size and strength for an efficient operation. Cokes of unsuitable quality will lead to a lower permeability in the bosh zone and hamper the furnace operation [2]. The viscosity of bosh slags and their tendency for static holdup in the coke bed of the bosh region in the blast furnace together play an important role in the process operation by directly influencing the free movement of both burden and furnace gas and thereby affecting the process efficiency. The impervious and viscous liquid formed by slag and molten iron does not allow the ascending gas to flow through it. Only the permeable coke layers, also known as coke-slits, distribute the gas and allow it to flow upwards [3]. Hence, the wetting property of bosh slag with coke surface directly affects the bed permeability. The current work discusses more concisely the novel laboratory scale experimental method to investigate the wetting behaviour of different slags with various industrial coke samples under attainable simulated conditions of the bosh region as shown by Bhattacharyya et al. [4]. The results depict the variation of coke quality (in terms of reactivity) and slag basicity as the main factors of different wetting situations. Novel sets of experiments have also been performed to find out the wetting phenomenon between coke and hot metal interface.

\section{Background}

The aim of this work is to achieve a closer process simulation under laboratory scale conditions. George et al. explain the flow mechanism of molten slag through coke channels [5] and coke packed beds [6]. These studies have
Fig. 2: Test setup. (a) Coke sample with slag bead before entering the furnace, (b) Zoomed part of fig. (a), (c) Coke substrate and slag bead on the refractory plate
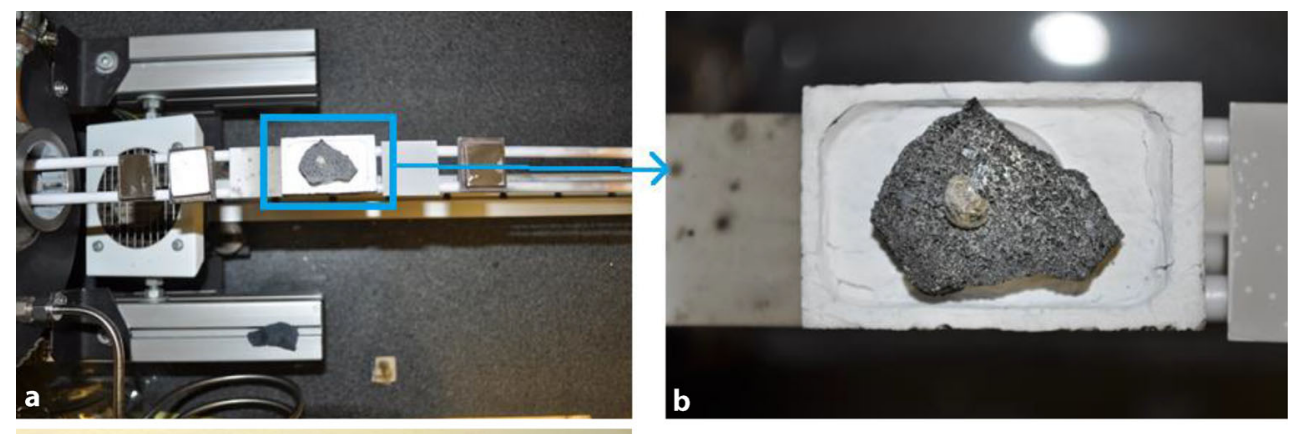

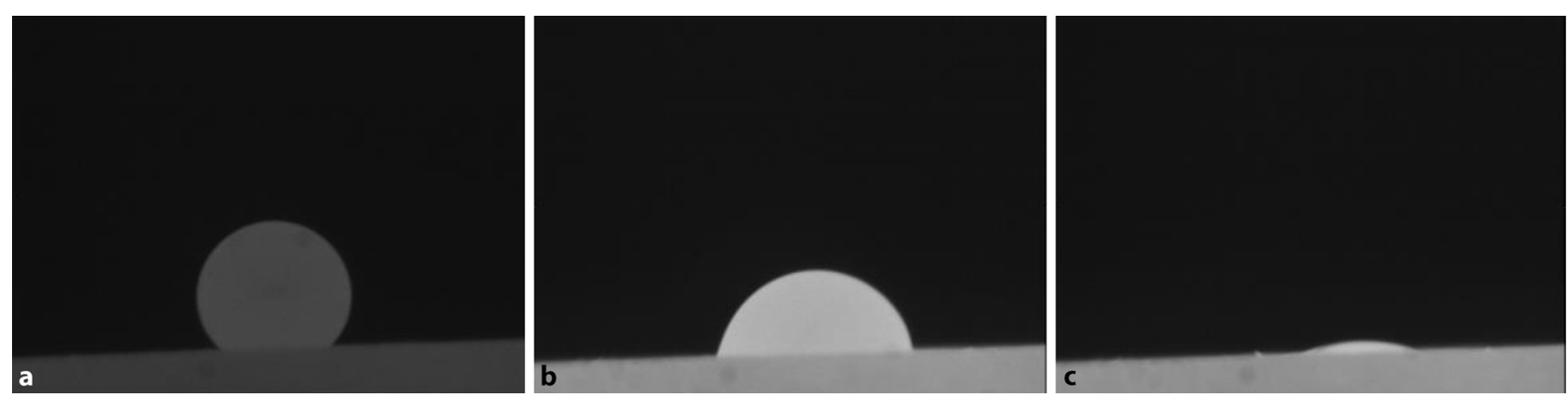

Fig. 3: Molten slag on coke surface at $1480^{\circ} \mathrm{C},(\mathrm{b})$ Change of contact angle at $1593^{\circ} \mathrm{C},(\mathrm{c})$ Slag droplet just before sinking during holding at $1600^{\circ} \mathrm{C}$

\begin{tabular}{|llll|}
\hline $\begin{array}{l}\text { TABLE 2: } \\
\text { Proximate analysis (all values are in }\end{array}$ & mass \%) \\
\hline & C1 & C2 & C3 \\
\hline Ash & 10.70 & 10.10 & 9.35 \\
\hline $\begin{array}{l}\text { Volatile Mat- } \\
\text { ter }\end{array}$ & 0.19 & 0.37 & 0.65 \\
\hline Moisture & 3.4 & 3.15 & 2.04 \\
\hline Fixed Carbon & 85.71 & 86.38 & 87.96 \\
\hline
\end{tabular}

\begin{tabular}{|c|c|c|c|}
\hline & C1 & C2 & C3 \\
\hline $\begin{array}{l}\text { CRI (Coke } \\
\text { Reactivity } \\
\text { Index) }\end{array}$ & 26.65 & 28.2 & 30.2 \\
\hline $\begin{array}{l}\text { CSR (Coke } \\
\text { Strength af- } \\
\text { ter Reaction) }\end{array}$ & 58.3 & 61.0 & 64.05 \\
\hline
\end{tabular}

been designed to find out the high temperature flow phenomena through packed beds. Husslage et al. have characterized the flow of both slag and hot metal through coke packed beds [7]. Interaction and interfacial reactions between coke analogues (pulverized and pressed coke substrates) or synthetic graphite/slag interface have been studied by various researchers in the recent past [8-10].

Bhattacharyya et al. [4] have showed an effective way of using industrial coke specimens directly in the experiments instead of using synthetic graphite or coke analogues in order to remain as closely as possible to actual process conditions. As a further step, to simulate the comparable porous coke structure at the bosh zone (after solution loss reaction), the coke pieces (later to be used as substrates) were treated under standard CRI (Coke Reactivity Index) conditions as per ISO 18894. [11] These coke pieces were used as the substrates against slag beads prepared by melting in the laboratory as well as real hot metal samples from the industry.

\section{Experimental Procedure}

The experiments performed in the current work have been done in a number of successive steps. To make it easier to understand, the whole experimental framework can be compartmentalized into the following steps -

Step 1: Production of thin coke pieces (to be used as substrates later) from bigger lumps

Step 2: Laboratory melting and preparation of slag samples

Step 3: CRI treatment of coke pieces

Step 4: Drop Shape Analysis (DSA) or Sessile Drop Test (SDT) of coke/slag combinations

\subsection{Step 1}

Three types of industrial blast furnace cokes (C1, C2, and C3) from different origins were used. The samples for DSA tests were obtained from bigger lumps by cutting thin sections of coke using a boron carbide cutting wheel. The sections were cut parallel to one direction in order to achieve almost parallel sides of the substrate material. The thickness of the sections was maintained in the range of $2-3 \mathrm{~mm}$.

\subsection{Step 2}

A four component slag system consisting of $\mathrm{CaO}, \mathrm{MgO}$, $\mathrm{Al}_{2} \mathrm{O}_{3}$, and $\mathrm{SiO}_{2}$ were used for the purpose of the experiments. The components were varied in order to get four slags of different basicities. The exact amounts of components which correspond to actual slag compositions in the bosh region were acquired from industrial data as well as from standard literature [3]. The two component (B2) and four component (B4) basicities are calculated as follows -

$$
\begin{aligned}
& \mathrm{B} 2=(\% \mathrm{CaO}) /\left(\% \mathrm{SiO}_{2}\right) \\
& \mathrm{B} 4=(\% \mathrm{CaO}+\% \mathrm{MgO}) /\left(\% \mathrm{SiO}_{2}+\% \mathrm{Al}_{2} \mathrm{O}_{3}\right)
\end{aligned}
$$

The slag components are shown in Table 1 . The viscosity values are calculated from Factsage 6.4 at $1600^{\circ} \mathrm{C}$, which is above the liquidus temperature for all slags. A high alumina slag was also taken into consideration.

The individual oxide components were taken in fine powder form in their respective mass percentages and mixed extensively to make a homogenous mixture of fine powders. Then the powder was filled in a platinum crucible and heated up to $1700^{\circ} \mathrm{C}$ in a high temperature vertical tube furnace (GERO-1700). The melt was allowed to diffuse for 


\begin{tabular}{|c|c|c|c|c|}
\hline \multicolumn{5}{|c|}{$\begin{array}{l}\text { TABLE 4: } \\
\text { Observations for different CRI treated coke/slag combination tests (Please ref } \\
\text { in 4.1) }\end{array}$} \\
\hline \multicolumn{4}{|c|}{ Increasing Reactivity } & \multirow{6}{*}{ Increasing Viscosity } \\
\hline & C1 & $\mathrm{C2}$ & $\mathrm{C3}$ & \\
\hline Slag IV & $\mathrm{HF}$ & $\mathrm{HF}$ & $\mathrm{HF}$ & \\
\hline Slag I & $\mathrm{H}$ & $\mathrm{H}$ & $\mathrm{H}$ & \\
\hline Slag II & $\mathrm{H}$ & I & I & \\
\hline Slag III & $\mathrm{H}$ & I & I & \\
\hline
\end{tabular}

\begin{tabular}{|c|c|c|c|}
\hline \multicolumn{4}{|c|}{$\begin{array}{l}\text { TABLE 5: } \\
\text { Observations for untreated coke/slag combination } \\
\text { tests (Please refer to the abbreviations mentioned in } \\
\text { 4.1) }\end{array}$} \\
\hline & C1 & C2 & C2 \\
\hline Slag I & HF, P & HF, P & HF, P \\
\hline
\end{tabular}

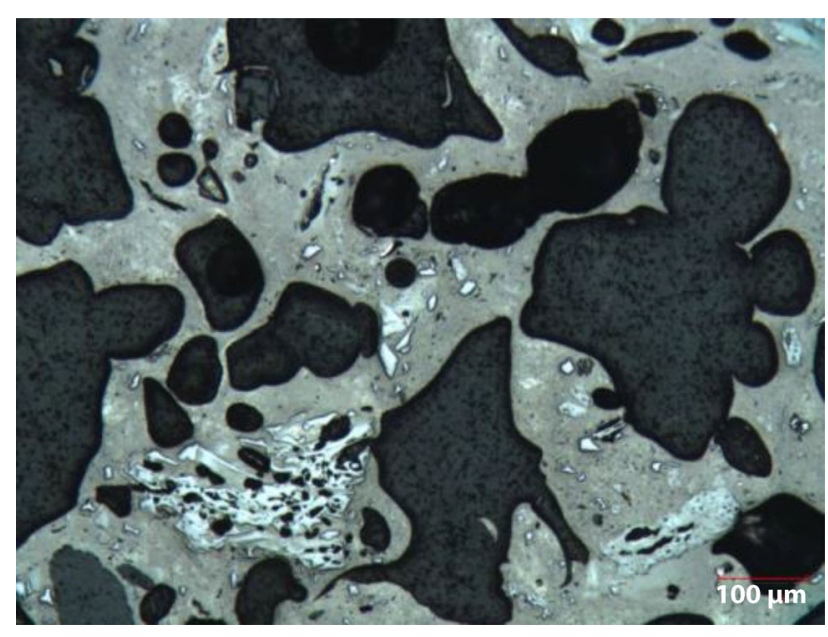

Fig. 4: Microstructure of coke showing distribution of large pores (Sample C3)

three hours. Then the crucible was taken out at hot condition $\left(1700^{\circ} \mathrm{C}\right)$, and the melt was immediately poured into cold water to get small glassy beads of slag. These beads were used later for DSA tests.

\subsection{Step 3}

As the coke lumps descend through the stack of the blast furnace, they are attacked by reactive gases. The CRI test is the globally accepted standard to find out the coke reactivity under blast furnace conditions. The CRI tests were performed at the reduction metallurgy laboratory of the Chair of Ferrous Metallurgy, Montanuniversität Leoben. For reactivity tests, a vertical tube furnace, constructed by
Siemens VAI Metals Technologies, Austria, was used. The equipment and procedure for determining the reactivity and strength of the coke samples are based on the standard testing procedure of ISO 18894 (2006) [11]. The thin coke sections prepared before were placed inside the retort for the CRI test period and then taken out and further used as substrates for DSA tests. In this way, an effort has been made to simulate the porous coke structure which is similar to the coke structure in the bosh region.

\subsection{Step 4}

The DSA tests were performed using a high-temperature horizontal tube furnace (Manufacturer - Krüss $\mathrm{GmbH}$, Model - DSA10 HT) in which the substrate along with the droplet is placed and heated at the desired temperature. The magnified image of the droplet is captured by a FALCON Image Grabber camera. The images could be processed using the Windows based software SW 21 (DSA1 v.1.80) for automated contact angle measurements using Young-Laplace curve fitting method. The furnace is shown in Fig. 1.

The following heating program was used for all coke/ slag or coke/hot metal combinations. All the steps were performed in an argon ( $\operatorname{Ar} 5.0)$ atmosphere.

- $15^{\circ} \mathrm{C} / \mathrm{min}$ until $1200^{\circ} \mathrm{C}$

- $10^{\circ} \mathrm{C} / \mathrm{min}$ thereafter

- Holding at $1600^{\circ} \mathrm{C}$ for $30 \mathrm{~min}$

- Program Stops

- Cooling in furnace to room temperature

Fig. 2 shows the preliminary steps for the tests. The coke sample together with the slag bead is placed on a protective refractory plate and then pushed into the middle of the furnace by two parallel rails. A platinum thermocouple (Type B) detects the temperature. The mass of the slag bead is always approximately $1 / 10^{\text {th }}$ of the coke piece, i.e. if the coke piece has a mass of $1 \mathrm{~g}$, the slag bead should have a mass of around $0.1 \mathrm{~g}$. For hot metal (HM) samples, the mass of the $\mathrm{HM}$ piece is around $1 / 2$ of the mass of the coke substrate. 
Fig. 5: C2/Slag ll combination, Temperature-approx. $1570^{\circ} \mathrm{C}$, (a) The slag droplet just before sinking, (b) After approx. one minute, the tiny droplet oozing out from surface (marked with a red circle)
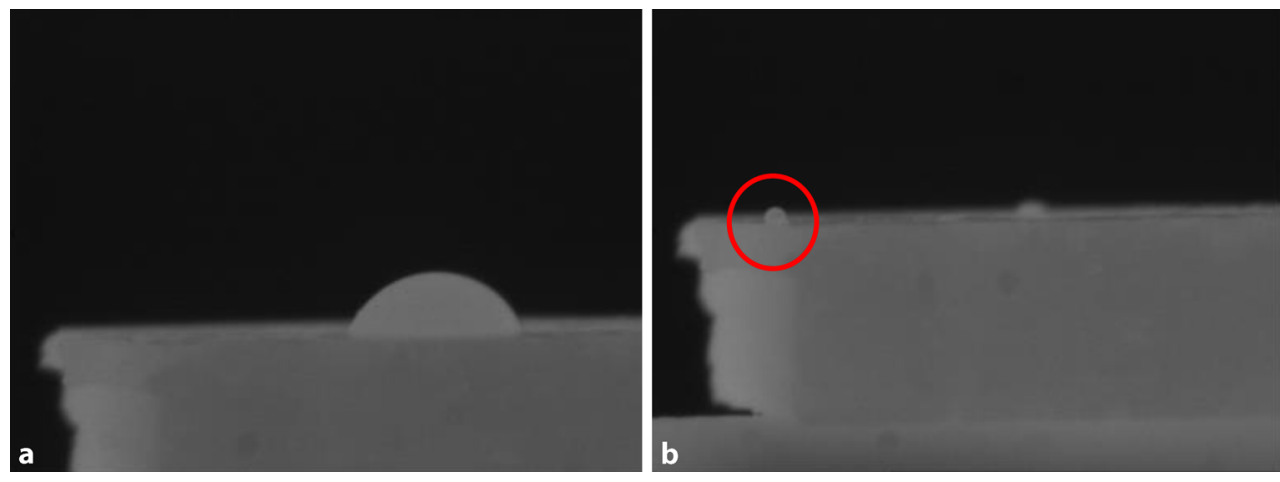

\begin{tabular}{|llllll|}
\hline \multicolumn{4}{l}{ TABLE 6: } \\
Hot metal composition (all values are in mass $\%)$
\end{tabular}

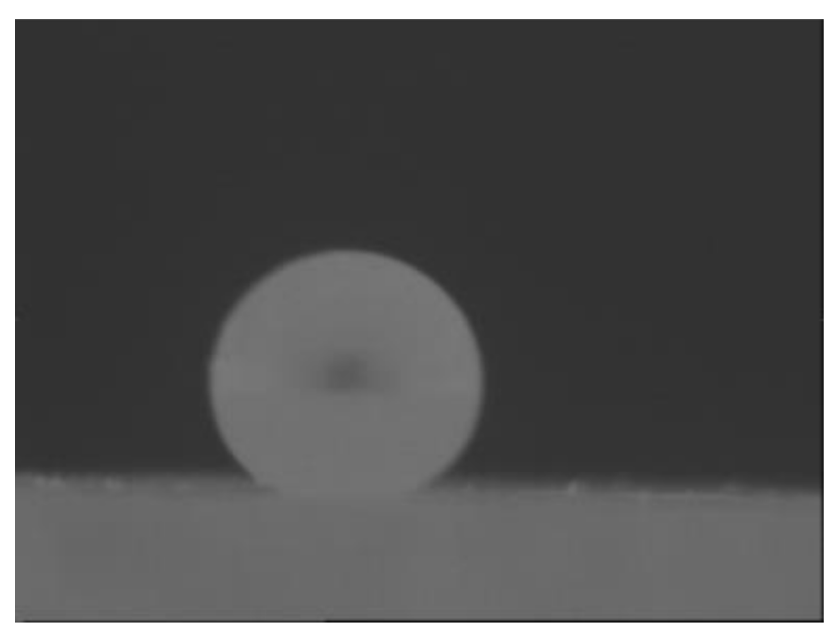

Fig. 6: $\mathrm{HM}$ drop on coke substrate at $1600^{\circ} \mathrm{C}$ showing wetting to a very little extent

A representative experimental observation is shown in Fig. 3. (C1/Slag II combination) -

\section{Results and Discussion}

The proximate analyses of the coke samples are shown in Table 2.

The CRI and CSR values are listed in Table 3.

\subsection{Coke/Slag Experiments}

All the coke/slag combinations have been performed with $\mathrm{CRI}$ test treated coke samples. However, in order to compare, all the coke samples in untreated condition (raw coke) have also been tested with Slag I. The tests have been repeated a few times to check for acceptable reproducibility.

Every coke/slag combination provided significant observations. In all cases of the treated samples, the slag droplet infiltrates the coke substrate through the pores, sometimes even before reaching $1600^{\circ} \mathrm{C}$. The descriptions of all possible phenomena are listed below. Letters in brackets represent each corresponding phenomenon.

- Complete infiltration of the slag droplet in coke before reaching $1600^{\circ} \mathrm{C}$ (I)

- The droplet remains until $1600^{\circ} \mathrm{C}$ and disappears during the holding time $(\mathbf{H})$

- The droplet does not disappear and remains on the surface after holding and cooling from $1600^{\circ} \mathrm{C}$ (HF)

- Strong pulsation of droplet during heating/holding (P)

Table 4 summarizes the observation for each CRI test treated coke/slag combination. Tests with untreated samples are listed separately.

From the matrix given in Table 4, it can be inferred that cokes with lower reactivity values show more wettability at higher temperatures than cokes with higher CRI values. In parallel, it can also be concluded that slags with low viscosity (i.e. high fluidity) show complete wetting at lower temperatures. So, given a combination of a high CRI coke along with a low viscosity slag, it will show full wetting at a much lower temperature and vice-versa. It can also be noted that, although C2 and C3 apparently exhibit the same behaviour, the spreading of the slag drop on the coke surface and sinking temperature are different in all cases.

In contrast, raw coke samples, when combined with Slag I, never showed full wetting, as shown in Table 5. The slag drop remains during the holding time and can be seen on the surface after cooling. Slag drops tested with untreated samples also show vigorous pulsation during the holding time. A possible reason could be the removal of the residual volatile matter present in the coke or gas generation by certain interfacial reactions.

The radical difference between the wetting behaviour of treated and untreated cokes occurs due to the difference of porosity in their structures. Coke is inherently a highly porous material. A typical pore and matrix microstructure of coke is shown in Fig. 4.

Many pores in a coke structure are long and interconnected. In one experiment, pictures acquired from the DST instrument show that a slag droplet sinks inside the coke substrate in one area and little later oozes out from another part of the coke sample (Fig. 5). Long interconnected pores inherent to the coke structure are broadened after CRI treatment and can hold some slag in the lumps. 


\subsection{Coke/Hot Metal Experiments}

The interaction between coke and hot metal is completely different from that between coke and slag. The chemical analysis of the industrial HM sample is shown in Table 6.

The HM sample exhibits an almost completely non-wetting behaviour with cokes. Even with the highly porous CRItreated coke samples, it shows almost no wetting (Fig. 6).

\section{Conclusion}

The current work is an attempt to demonstrate the wetting behaviour of coke with different liquid phases under the simulated conditions of the bosh zone of the blast furnace. This method uses coke pieces treated under ISO 18894 conditions as the substrate material. A comparison of the wetting behaviour between treated and untreated coke samples implies that the coke quality, especially the $C R I$ value, is a key to predict its performance in the bosh zone. Tests with different slags demonstrate the effect of chemical composition and viscosity on the wetting process. Some ideas about the hold-up behaviour of a particular slag can be inferred from these experiments. This work also points out that hot metal does not contribute significantly to the holdup phenomenon. This technique provides a better understanding of the interfacial phenomena in the lower zone of the blast furnace.

Open access funding provided by Montanuniversität Leoben

Open Access This article is distributed under the terms of the Creative Commons Attribution 4.0 International License (http://creativecommons. org/licenses/by/4.0/), which permits unrestricted use, distribution, and reproduction in any medium, provided you give appropriate credit to the original author(s) and the source, provide a link to the Creative Commons license, and indicate if changes were made.

\section{References}

1. Babich, A.; Senk, D.; Gudenau, H. W.: Effect of coke reactivity and nut coke on blast furnace operation, Ironmaking and Steelmaking, 36 (2009), No. 3, pp 222-229

2. Ghosh, A.; Chatterjee, A.: Overview of Blast Furnace Ironmaking, Ironmaking and Steelmaking: Theory and Practice, Delhi: PHI Learning Pvt. Ltd., 2013, pp 24-38

3. Biswas, A. K.: Principles of Blast Furnace Ironmaking, Calcutta: SBA Publications, 1984, pp 1-13 and 339-341

4. Bhattacharyya, A.; Schenk, J.; Arth, G.; Stocker, H.; Thaler, C.: Experimental Analysis of the Interfacial Wetting Phenomena between Slag and Coke Surface under Simulated Conditions of the Bosh Region of Blast Furnace, AISTECH 2015 Proceedings, Cleveland, USA, May 2015, 2015

5. George, H. L.; Monaghan, B. J.; Longbottom, R. J.; Chew, S. J.; Austin, P. R.: Flow of Molten Slag through Coke Channels, ISIJ International, 53 (2013), No. 7, pp 1172-1179

6. George, H. L.; Longbottom, R. J.; Chew, S. J.; Monaghan, B. J.: Flow of Molten Slag through a Coke Packed Bed, ISIJ International, 54 (2014), No. 4, pp 820-826

7. Husslage, W. M.; Reuter, M. A.; Heerema, R. H.; Bakker, T.; Steeghs, A. G. S.: Flow of Molten Slag and Iron at $1500^{\circ} \mathrm{C}$ to $1600^{\circ} \mathrm{C}$ through Packed Coke Beds, Metallurgical And Materials Transactions B, 36B (2005), pp. 765- 776

8. Mehta, A. S.; Sahajwalla, V.: Coal-char/Slag Interactions during Pulverised Coal Injection in a Blast Furnace: Reaction Kinetics and Wetting Investigations, ISIJ International, 43 (2003), No. 10, pp 1512-1518

9. Wook Kang, T.; Sushil Gupta, N. Saha-Chaudhury, N.; Sahajwalla, V.: Wetting and Interfacial Reaction Investigations of Coke/Slag Systems and Associated Liquid Permeability of Blast Furnaces, ISIJ International, 45 (2005), No. 11, pp 1526-1535

10. Sahajwalla, V.; Mehta, A. S.; Khanna, R.: Influence of Chemical Compositions of Slag and Graphite on the Phenomena Occurring in the Graphite/Slag Interfacial Region, Metallurgical And Materials Transactions B, Volume 35b (2004), pp 75-83

11. ISO 18894:2006, Coke - Determination of coke reactivity index (CRI) and coke strength after reaction (CSR) 